\title{
Question Marks Left Over a Quantitative Assessment of Apolipoprotein C3 Gene Polymorphisms
}

\author{
Philipp G. Sand \\ Department of Psychiatry, University of Regensburg, and Danuvius Klinik GmbH, Ingolstadt, Germany
}

[Received March 25, 2016; Revised May 2, 2016; Accepted May 2, 2016]

Dear Editor,

On the occasion of the 2012 annual meeting of the American Society of Human Genetics in San Francisco, the scientific press concluded to a sobering "genetic influences on disease remain hidden" after discussing, among others, the progress made in the field of cardiovascular genetics [1]. In a recent attempt to resolve some of the inconsistent findings, Zhang and coworkers [2] have presented a quantitative analysis of $A P O C 3$ variants in coronary heart disease. Unfortunately, only a fraction of the previously published data have been considered and, using the authors' inclusion criteria, over 10000 alleles are missing from the investigation [3-8]. What is more, incorrect allele counts have led to biased effects for the SstI polymorphism, causing the riskenhancing allele to become protective [9] and vice versa [10]. Allele counts for the T-455C variant also differ from the published data [11] and are further compromised by duplicates from overlapping samples [11,12]. With regard to both $\mathrm{T}-455 \mathrm{C}$ and $\mathrm{C}-482 \mathrm{~T}$, the vast majority of allele frequencies reported in Table 1 of the article [2] are either in error [11,13-18], missing [12], or entirely fictional [19]. Finally, failure to identify $\mathrm{C} 3175 \mathrm{G}$ as a synonym of the SstI polymorphism has led to the omission of more alleles from a publication which served to extract data on T-455C and C-482T [13].

On the whole, the article calls for numerous issues to be ironed out prior to claiming, or to refuting, significant effects of the three $A P O C 3$ variants on coronary heart disease susceptibility.

\section{Acknowledgements}

This research received no specific grant from any funding agency in the public, commercial, or not-for-profit sectors.

\section{Conflict of interest}

The author reports no conflict of interest.

\section{References}

[1] Kaiser J (2012). Human genetics. Genetic influences on disease remain hidden. Science, 338:1016-1017.

[2] Zhang JZ, Xie X, Ma YT, Zheng YY, Yang YN, Li XM, Fu ZY, Dai CF, Zhang MM, Yin GT, Liu F, Chen BD, Gai MT (2016). Association between Apolipoprotein CIII Gene Polymorphisms and Coronary Heart Disease: A Meta-analysis. Aging Dis, 7:36-44.

[3] Miettinen HE, Korpela K, Hämäläinen L, Kontula K (1994). Polymorphisms of the apolipoprotein and angiotensin converting enzyme genes in young North Karelian patients with coronary heart disease. Hum Genet, 94:189-192.

[4] Baroni MG, Berni A, Romeo S, Arca M, Tesorio T, Sorropago G, Di Mario U, Galton DJ (2003). Genetic study of common variants at the Apo E, Apo AI, Apo CIII, Apo B, lipoprotein lipase (LPL) and hepatic lipase (LIPC) genes and coronary artery disease (CAD): variation in LIPC gene associates with clinical outcomes in patients with established CAD. BMC Med Genet, 4:8.

[5] Masana L, Febrer G, Cavanna J, Baroni MG, Marz W, Hoffmann MM, Shine B, Galton DJ (2001). Common genetic variants that relate to disorders of lipid transport in Spanish subjects with premature coronary artery disease. Clin Sci, 100:183-190.

*Correspondence should be addressed to: Philipp G. Sand, M.D., Department of Psychiatry, University of Regensburg Universitaetsstrasse 84, 93042 Regensburg, Germany. Email: philipp.sand@ukr.de

Copyright: () 2016 Sand, PG. This is an open-access article distributed under the terms of the Creative Commons Attribution License, which permits unrestricted use, distribution, and reproduction in any medium, provided the original author and source are credited. 
[6] Bhanushali AA, Das BR (2010). Influence of genetic variants in the apolipoprotein $\mathrm{A} 5$ and $\mathrm{C} 3$ gene on lipids, lipoproteins, and its association with coronary artery disease in Indians. J Community Genet, 1:139-148.

[7] AshokKumar M, Subhashini NG, SaiBabu R, Ramesh A, Cherian KM, Emmanuel C (2010). Genetic variants on apolipoprotein gene cluster influence triglycerides with a risk of coronary artery disease among Indians. Mol Biol Rep, 37:521-527.

[8] Wong WM, Hawe E, Li LK, Miller GJ, Nicaud V, Pennacchio LA, Humphries SE, Talmud PJ (2003). Apolipoprotein AIV gene variant S347 is associated with increased risk of coronary heart disease and lower plasma apolipoprotein AIV levels. Circ Res, 92:969-975.

[9] Aalto-Setälä K, Kontula K, Sane T, Nieminen M, Nikkilä E (1987). DNA polymorphisms of apolipoprotein A-I/C-III and insulin genes in familial hypertriglyceridemia and coronary heart disease. Atherosclerosis, 66:145-152.

[10] Izar MC, Fonseca FA, Ihara SS, Kasinski N, Sang WH, Lopes IE, Pinto Ldo E, Relvas WG, Lourenço D, Tufik S, de Paola AA, Carvalho AC (2003). Risk Factors, biochemical markers, and genetic polymorphisms in early coronary artery disease. Arq Bras Cardiol, 80:379395.

[11] Olivieri O, Stranieri C, Bassi A, Zaia B, Girelli D, Pizzolo F, Trabetti E, Cheng S, Grow MA, Pignatti PF, Corrocher R (2002). ApoC-III gene polymorphisms and risk of coronary artery disease. J Lipid Res, 43:14501457.

[12] Martinelli N, Trabetti E, Bassi A, Girelli D, Friso S, Pizzolo F, Sandri M, Malerba G, Pignatti PF, Corrocher $\mathrm{R}$, Olivieri $\mathrm{O}$ (2007). The $-1131 \mathrm{~T}>\mathrm{C}$ and S19W APOA5 gene polymorphisms are associated with high levels of triglycerides and apolipoprotein C-III, but not with coronary artery disease: an angiographic study. Atherosclerosis, 191:409-417.
[13] Tobin MD, Braund PS, Burton PR, Thompson JR, Steeds R, Channer K, Cheng S, Lindpaintner K, Samani NJ (2004). Genotypes and haplotypes predisposing to myocardial infarction: a multilocus case-control study. Eur Heart J, 25:459-467.

[14] Yu J, Huang J, Liang Y, Qin B, He S, Xiao J, Wang H, Zhong R (2011). Lack of association between apolipoprotein C3 gene polymorphisms and risk of coronary heart disease in a Han population in East China. Lipids Health Dis, 10:200.

[15] Dallongeville J, Cottel D, Montaye M, Codron V, Amouyel P, Helbecque $\mathrm{N}$ (2006). Impact of APOA5/A4/C3 genetic polymorphisms on lipid variables and cardiovascular disease risk in French men. Int J Cardiol, 106:152-156.

[16] Bi N, Yan SK, Li GP, Yin ZN, Xue H, Wu G, Chen BS (2005). Polymorphisms in the apolipoprotein A5 gene and apolipoprotein $\mathrm{C} 3$ gene in patients with coronary artery disease. Zhonghua Xin Xue Guan Bing Za Zhi, 33:116-121.

[17] Ding Y, Zhu MA, Wang ZX, Zhu J, Feng JB, Li DS (2012). Associations of polymorphisms in the apolipoprotein APOA1-C3-A5 gene cluster with acute coronary syndrome. J Biomed Biotechnol, 2012:509420.

[18] Muendlein A, Saely CH, Marte T, Schmid F, Koch L, Rein P, Langer P, Aczel S, Drexel H (2008). Synergistic effects of the apolipoprotein $\mathrm{E}$ epsilon3/epsilon2/epsilon4, the cholesteryl ester transfer protein TaqIB, and the apolipoprotein $\mathrm{C} 3-482 \mathrm{C}>\mathrm{T}$ polymorphisms on their association with coronary artery disease. Atherosclerosis, 199:179-186.

[19] Sediri Y, Kallel A, Feki M, Mourali S, Elasmi M, Abdessalem S, Mechmeche R, Jemaa R, Kaabachi N (2011). Association of a DNA polymorphism of the apolipoprotein AI-CIII-AIV gene cluster with myocardial infarction in a Tunisian population. Eur $\mathbf{J}$ Intern Med, 22:407-411. 


\section{Erratum to: Letter to the Editor}

Aging Dis. 2016 Jan 2;7(1):36-44.

doi: 10.14336/AD.2015.0709.

\section{Association Between Apolipoprotein C-III Gene Polymorphisms and the Risk of Coronary Heart Disease: a Meta-analysis}

Jing-Zhan Zhang, Xiang Xie, Yi-Tong Ma, Ying-Ying Zheng, Yi-Ning Yang, Xiao-Mei Li, Zhen-Yan Fu, Chuan-Fang Dai, Ming-Ming Zhang, Guo-Ting Yin, Fen Liu, Bang-Dang Chen, Min-Tao Gai

Department of Cardiology, First Affiliated Hospital of Xinjiang Medical University, Urumqi, 830054, China.

In light of Dr. Sands' letter, we have reanalyzed data from our meta-analysis of the association between apolipoprotein C-III gene polymorphisms and coronary heart disease (CHD)[1].Our original database searches did not recover several references cited by Dr. Sand[2-5], which we have now included, and we were unable to extract data useful for our analysis from two other references [6-7]. We have reexamined additional studies referred to by Dr.Sand [8-14] and recalculated our results accordingly.

The new calculations still show an association between the APOC3 SstI polymorphism and CHD under allelic contrast $(P<0.0001$, OR $=1.17,95 \% \mathrm{CI}=1.08$ 1.27), dominant genetic $(P=0.001, \mathrm{OR}=1.17,95 \% \mathrm{CI}=$ 1.07-1.29), and recessive genetic $(P=0.01$, OR $=1.36$, $95 \% \mathrm{CI}=1.07-1.73$ ) models; between the APOC3 T-455C polymorphism and CHD under allelic contrast (C vs. T, $P$ $=0.007, \mathrm{OR}=1.19,95 \% \mathrm{CI}=1.05-1.35)$ and dominant genetic $(\mathrm{CT}+\mathrm{CC}$ vs. TT, $P=0.0004, \mathrm{OR}=1.26,95 \% \mathrm{CI}$ $=1.11-1.43$ ), but no longer recessive genetic (CC vs. $\mathrm{CT}+\mathrm{TT}, P=0.12, \mathrm{OR}=1.25,95 \% \mathrm{CI}=0.95-1.66)$ models; and no association between the APOC3 C-482T polymorphism and $\mathrm{CHD}$ under allelic contrast (T vs. C, $P$ $=0.59, \mathrm{OR}=1.02,95 \% \mathrm{CI}=0.95-1.10)$, dominant genetic $(\mathrm{TT}+\mathrm{TC}$ vs. $\mathrm{CC}, P=0.17, \mathrm{OR}=1.08,95 \% \mathrm{CI}=0.97$ 1.20)or recessive genetic (TT vs. TC $+\mathrm{CC}, P=0.41$, OR $=0.94,95 \% \mathrm{CI}=0.82-1.09$ ) models. Our meta-analysis suggests that the APOC3 SstI polymorphism significantly increases, the APOC3 T-455C polymorphism may increase, and the APOC3 C-482Tpolymorphism shows no association with CHD susceptibility.

We sincerely apologize for the errors in our article.

PMID: 26816662 [PubMed] PMCID: PMC4723232

\section{References}

[1] Zhang JZ, Xie X, Ma YT, Zheng YY, Yang YN, Li XM, Fu ZY, Dai CF, Zhang MM, Yin GT, Liu F, Chen BD, Gai MT (2016). Association between Apolipoprotein C-III Gene Polymorphisms and Coronary Heart Disease: A Meta-analysis. Aging Dis, 7:36-44.

[2] Miettinen HE, Korpela K, Hämäläinen L, Kontula K (1994). Polymorphisms of the apolipoprotein and angiotensin converting enzyme genes in young North Karelian patients with coronary heart disease. Hum Genet, 94:189-192.

[3] Baroni MG, Berni A, Romeo S, Arca M, Tesorio T, Sorropago G, Di Mario U, Galton DJ (2003). Genetic study of common variants at the Apo E, Apo AI, Apo CIII, Apo B, lipoprotein lipase (LPL) and hepatic lipase (LIPC) genes and coronary artery disease (CAD): variation in LIPC gene associates with clinical outcomes in patients with established CAD. BMC Med Genet, 4:8.

[4] Bhanushali AA, Das BR (2010). Influence of genetic variants in the apolipoprotein A5 and C3 gene on lipids, lipoproteins, and its association with coronary artery disease in Indians. J Community Genet, 1:139-148.

[5] AshokKumar M, Subhashini NG, SaiBabu R, Ramesh A, Cherian KM, Emmanuel C (2010). Genetic variants on apolipoprotein gene cluster influence triglycerides with a risk of coronary artery disease among Indians. Mol Biol Rep, 37:521-527.

[6] Masana L, Febrer G, Cavanna J, Baroni MG, Marz W, Hoffmann MM, Shine B, Galton DJ (2001). Common genetic variants that relate to disorders of lipid transport in Spanish subjects with premature coronary artery disease. Clin Sci, 100:183-190.

[7] Wong WM, Hawe E, Li LK, Miller GJ, Nicaud V, Pennacchio LA, Humphries SE, Talmud PJ (2003). Apolipoprotein AIV gene variant S347 is associated with increased risk of coronary heart disease and lower plasma apolipoprotein AIV levels. Circ Res, 92:969-975.

[8] Olivieri O, Stranieri C, Bassi A, Zaia B, Girelli D, Pizzolo F, Trabetti E, Cheng S, Grow MA, Pignatti PF, Corrocher $\mathrm{R}$ (2002). ApoC-III gene polymorphisms and risk of coronary artery disease. J Lipid Res, 43:1450-1457.

[9] Li XD, Sun ZH, Yang ZY, et al. (2006). APOAl/C3 gene cluster polymorphisms and risk of coronary artery disease. Chin J Gerontol, 26:745-747.

[10] Han TL (2011). A5/C3 Gene cluser and the correlation to the patients with coronary artery disease in ShanDong coastal areas. Shandong University, 1-50.

[11] Martinelli N, Trabetti E, Bassi A, Girelli D, Friso S, Pizzolo F, Sandri M, Malerba G, Pignatti PF, Corrocher R, Olivieri O (2007). The $-1131 \mathrm{~T}>\mathrm{C}$ and S19W APOA5 gene polymorphisms are associated with high levels of triglycerides and apolipoprotein C-III, but not with coronary artery disease: an angiographic study. Atherosclerosis, 191:409-417.

[12] Liu HK, Li FX, Zhang SZ, et al. (2005). Association of Sst I Polymorphism in Apolipoprotein C3 Gene withHypertriglyceridaemia in Coronary Atherosclerotic Heart Disease and Type II Diabetes Mellitus in 
ChinesePopulation. Yi Chuan Xue Bao, 32:11-18.

[13] Liu HK (2005). Study on the association of single nucleotide polymorphisms in apolipoproteinAPOAl/C3/A4/A5 gene cluster with coronary heart disease and type II diabetes. Sichuan University, 1-116

[14] Tobin MD, Braund PS, Burton PR, Thompson JR, Steeds R, Channer K, Cheng S, Lindpaintner K, Samani NJ (2004). Genotypes and haplotypes predisposing to myocardial infarction: a multilocus case-control study. Eur Heart J, 25:459-467. 